\title{
PENERAPAN PEMBELAJARAN MATEMATIKA YANG MELIBATKAN KECERDASAN MAJEMUK DENGAN PENDEKATAN SAINTIFIK
}

\author{
${ }^{1)}$ Azin Taufik dan ${ }^{2)}$ Nuranita Adiastuty \\ Fakultas Keguruan dan Ilmu Pendidikan Universitas Kuningan \\ azin.taufik@gmail.com
}

\begin{abstract}
This research based on the result of preliminary observation at MTs Nurul Huda Beringin. Documentation of supervision by headmaster who has been held in the school, data showed that the learning mathematics with scientific approach applied by teachers are still not optimal. Based on documenttion of learning outcome students the data that there are $40 \%$ of students not reached the minimum competence criteria. Humans have nine types of intelegence, seven of the nine types of intelegence are: verbal/linguistic intelegence, visual/spatial, logical/mathematical, musical, bodily/kinesthetic, interpersonal and intrapersonal. This research is a classroom action research with qualitative descriptive approach implemented in class VII MTs Nurul Hudda Beringin, Cirebon, on the material relations and function. Based on the analysis we concluded that the study of mathematics involving multiple intelegences with scientific approach by the steps: 1) preliminary activities; 2) the core activities consist of observasing, ask, gather information, associates and communicate; and 3) the cover. While multiple intelegences involved in learning is verbal/linguistic intelegence, visual/spatial intelegence, logical/mathematical intelegence, musical intelegence, the intelegence of the body/kinesthetic, interpersonal and intrapersonal intelegence. In the first cycle, the average result of observation activities of students and teachers was $70 \%$ and $76 \%$ in the unfavorable and fairly category. In the second cycle, the average results of observation activities of students and teacher was $82 \%$ and $83 \%$, both in good categories. In the first cycle, the achievment of students VIII-A is a total of 18 students or $46 \%$ students take the final value more than 75 . In the second cycle, the achievment of student VIII-A is of the total of 31 students or $80 \%$ students obtain the final score more than 75 . So the achievment learning was increasing $34 \%$ from the first cycle to the second cycle.
\end{abstract}

Keywords: Multiple Intelegences, Scientific Approach 


\begin{abstract}
Abstrak
Penelitian ini di dasari pada hasil observasi awal yang dilakukan di MTs Nurul huda Beringin, dari hasil dokumentasi supervisi oleh kepala sekolah yang sudah dilaksanakan di sekolah tersebut diperoleh data bahwa pembelajaran matematika dengan pendekatan saintifik yang diterapkan oleh guru masih belum optimal, dari hasil dokumentasi hasil belajar siswa didapatkan data bahwa terdapat $40 \%$ siswa yang belum mencapai nilai kriteria ketuntasan minimal. Menurut Gardner (2011), manusia mempunyai sembilan jenis kecerdasan. Tujuh di antara sembilan jenis kecerdasan tersebut yaitu: kecerdasan verbal/linguistik, visual/spasial, logical/matematis, musikal, tubuh/kinestetik, interpersonal dan intrapersonal. Penelitian ini merupakan penelitian tindakan kelas dengan pendekatan kualitatif deskriptif yang dilaksanakan di kelas VIII A MTs Nurul Huda Beringin Cirebon, pada materi relasi dan fungsi. Berdasarkan hasil analisis data diperoleh kesimpulan bahwa pembelajaran matematika yang melibatkan kecerdasan majemuk dengan pendekatan saintifik dilaksanakan dengan langkah-langkah: 1) kegiatan pendahuluan; 2) kegiatan inti yang terdidi dari mengamati, menanya, mengumpulkan informasi, mengasosiasi, dan mengkomunikasikan; dan 3) penutup. Sedangkan kecerdasan majemuk yang terlibat dalam pembelajaran adalah kecerdasan verbal/lingusitik, kecerdasan visual/spasial, kecerdasan logikal/matematis, kecerdasan musikal, kecerdasan tubuh/kinestetik, kecerdasan interpersonal, dan kecerdasan intrapersonal. Pada siklus I, rata-rata hasil observasi aktivitas siswa dan guru adalah $70 \%$ dan $76 \%$ dalam kategori kurang baik dan cukup. Pada siklus II, rata-rata hasil observasi aktivitas siswa dan guru adalah $82 \%$ dan $83 \%$ dalam kategori baik . Pada siklus I, pencapaian prestasi belajar siswa kelas VIII-A adalah sebanyak 18 siswa atau $46 \%$ siswa memperoleh nilai akhir lebih dari 75. Pada siklus II, pencapaian prestasi belajar siswa kelas VIII-A adalah Sebanyak 31 siswa atau $80 \%$ siswa memperoleh skor akhir lebih dari 75. Sehingga peningkatan pencapaian prestasi belajar dari siklus I dan siklus II adalah sebesar 34\%.
\end{abstract}

Kata kunci: Kecerdasan Majemuk, Pendekatan Saintifik

\section{PENDAHULUAN}

\section{Latar Belakang}

Berdasarkan hasil observasi yang dilakukan peneliti di MTs Nurul Huda beringin Cirebon pada bulan November 2014, bahwa kurikulum yang diterapkan di MTs Nurul Huda ini adalah kurikulum 2013, dengan diterapkannya kurikulum 2013 maka menuntut guru untuk membelajarkan mata pelajaran dengan menggunakan pendekatan saintifik. Akan tetapi, guru matematika di MTs Nurul Huda Beringin dalam memberikan pembelajaran matematika menggunakan metode ceramah yang terpusat ke guru, hal ini oleh guru dipandang lebih efektif dari pada menggunakan metode pembelajaran matematika inovatif, salah satu yang 
menjadi alasan adalah karena guru kesulitan dalam menerapkan pembelajaran dengan kurikulum 2013, guru pernah mencoba menggunakan pendekatan saintifik di dalam mengajar, akan tetapi banyak siswa yang tidak dapat memahami materi dengan baik, sehingga guru menerangkannya dengan metode ceramah, selain itu ketersediaan sarana dan prasarana yang kurang memadai di sekolah juga menjadi kendala yang menghambat pelaksanaan pembelajaran dengan menggunakan kurikulum 2013.

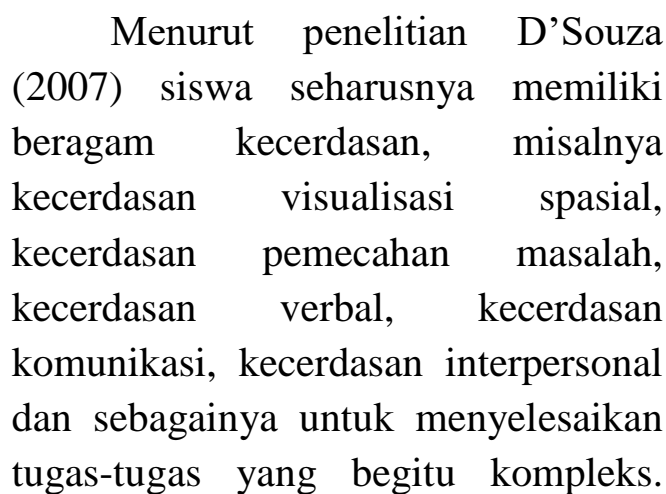

Teori kecerdasan tersebut salah satunya ditemukan dan disebut oleh Howard Gardner sebagai teori kecerdasan majemuk (Multiple Intelligences). Menurut Gardner (2011), manusia mempunyai tujuh kecerdasan, yaitu: kecerdasan linguistik-verbal, kecerdasan logikal/matematik, kecerdasan spasialvisual, kecerdasan kinestetik, kecerdasan musikal-ritmik, kecerdasan intrapersonal, dan kecerdasan interpersonal.

Menurut DePorter, dkk (1999: 85) setiap orang (guru) memiliki kecenderungan gaya mengajar yang sama dengan gaya belajar masingmasing. Padahal, pembelajaran bisa optimal jika disampaikan dengan gaya mengajar yang sesuai dengan masingmasing gaya belajar dan kecerdasan dominan siswa. Pembelajaran yang dilakukan di sekolah seharusnya juga didesain untuk mengembangkannya.

Dari uraian tersebut peneliti memandang perlu untuk melakukan penelitian penerapan pembelajaran matematika dengan melibatkan kecerdasan majemuk melalui penelitian yang berjudul "Penerapan Pembelajaran Matematika yang Melibatkan Kecerdasan Majemuk dengan Pendekatan Saintifik". Penelitian ini bertujuan untuk mendeskripsikan penerapan pembelajaran matematika yang melibatkan kecerdasan majemuk dengan pendekatan saintifik.

\section{KAJIAN TEORI}

Proses pembelajaran pada Kurikulum 2013 untuk semua jenjang dilaksanakan dengan menggunakan pendekatan ilmiah (saintifik). Pendekatan saintifik dalam pembelajaran disajikan sebagai berikut:

a. Mengamati

Kegiatan mengamati dalam pembelajaran sebagaimana disampaikan dalam Permendikbud Nomor 81a, hendaklah guru membuka secara luas dan bervariasi kesempatan peserta didik untuk melakukan pengamatan melalui kegiatan: melihat, menyimak, mendengar, dan membaca. Guru 
memfasilitasi peserta didik untuk melakukan pengamatan, melatih mereka untuk memperhatikan (melihat, membaca, mendengar) hal yang penting dari suatu benda atau objek. Adapun kompetensi yang diharapkan adalah melatih kesungguhan, ketelitian, dan mencari informasi.

\section{b. Menanya}

Dalam kegiatan mengamati, guru membuka kesempatan secara luas kepada peserta didik untuk bertanya mengenai apa yang sudah dilihat, disimak, dibaca atau dilihat. Guru perlu membimbing peserta didik untuk dapat mengajukan pertanyaan: pertanyaan tentang yang hasil pengamatan objek yang konkrit sampai kepada yang abstra berkenaan dengan fakta, konsep, prosedur, atau pun hal lain yang lebih abstrak.

\section{c. Mengumpulkan Informasi \\ Dalam Permendikbud Nomor} 81a Tahun 2013, aktivitas mengumpulkan informasi dilakukan melalui eksperimen, membaca sumber lain selain buku teks, mengamati objek/ kejadian/, aktivitas wawancara dengan nara sumber dan sebagainya. Adapun kompetensi yang diharapkan adalah mengembangkan sikap teliti, jujur,sopan, menghargai pendapat orang lain, kemampuan berkomunikasi, menerapkan kemampuan mengumpulkan informasi melalui berbagai cara yang dipelajari, mengembangkan kebiasaan belajar dan belajar sepanjang hayat. d. Mengasosiasikan/ Mengolah
Informasi/Menalar
Kegiatan "mengasosiasi/ mengolah informasi/ menalar" dalam kegiatan pembelajaran sebagaimana disampaikan dalam Permendikbud Nomor 81a Tahun 2013, adalah memproses informasi yang sudah dikumpulkan baik terbatas dari hasil kegiatan mengumpulkan/eksperimen maupun hasil dari kegiatan mengamati dan kegiatan mengumpulkan informasi. Adapun kompetensi yang diharapkan adalah mengembangkan sikap jujur, teliti, disiplin, taat aturan, kerja keras, kemampuan menerapkan prosedur dan kemampuan berpikir induktif serta deduktif dalam menyimpulkan.

e. Menarik kesimpulan

Kegiatan menyimpulkan dalam pembelajaran dengan pendekatan saintifik merupakan kelanjutan dari kegiatan mengolah data atau informasi. Setelah menemukan keterkaitan antar informasi dan menemukan berbagai pola dari keterkaitan tersebut, selanjutnya secara bersama-sama dalam satu kesatuan kelompok, atau secara individual membuat kesimpulan.

\section{f. Mengkomunikasikan}

Kegiatan "mengkomunikasikan" dalam kegiatan pembelajaran sebagaimana disampaikan dalam Permendikbud Nomor 81a Tahun 2013, adalah menyampaikan hasil pengamatan, kesimpulan berdasarkan hasil analisis secara lisan, tertulis, atau media lainnya. 
Piaget (dalam Efendi, 2005:83) mengemukakan bahwa kecerdasan adalah apa yang kita gunakan pada saat kita tidak tahu apa yang harus dilakukan. Seseorang dikatakan cerdas jika ia terampil dalam menemukan jawaban yang benar untuk masalah pilihan hidup. Tentu, keterampilan ini dapat diasah terus menerus untuk menyelesaikan permasalahan hidup yang lebih kompleks. Lebih lanjut Calvin (dalam Efendi, 2005:83) mengatakan, "kecerdasan adalah sebuah proses, bukan sebuah tempat." Dengan kata lain kecerdasan bukanlah sesuatu yang diam di tempat, tetapi sesuatu yang bergerak dan terus berkembang melalui proses pembelajaran hidup.

Teori kecerdasan majemuk (multiple intelligences) ditemukan dan dikembangkan oleh Howard Gardner, seorang ahli psikologi pendidikan dan perkembangan dari Graduate School of Education, Universitas Harvard, Amerika Serikat. Ia mulai memperkenalkan kecerdasan majemuk melalui bukunya yang berjudul Frames of Mind (2011) yang disempurnakan dengan penerapannya di dunia pendidikan dalam buku Multiple Intelligence: Theory and Practice (1993) dan penambahan jenis kecerdasan dalam teorinya melalui buku Intelligence Reframed (1999).

Dalam menentukan jenis kecerdasan majemuk, Gardner menggunakan delapan kriteria yang sering digunakan untuk menentukan apakah suatu kemampuan manusia sungguh dapat digolongkan sebagai kecerdasan atau tidak. Kriteria-kriteria kemampuan yang dikemukakan Gardner (2011) tersebut adalah sebagai berikut.

(1) Potential isolation by brain damage; (2) The Existence of Idiots Savants, Prodigies, and Other Exceptional Individuals; (3) An Identifiable Core Operation or Set of Operations; (4) A Distinctive Developmental History, Along with a Definable Set of Expert "End State", Performances; (5) Support from psychometric findings; (6) Support from experimental psychological tasks; (7) Support from Psychometric Findings; (8) Susceptibility to encoding in a symbol system.

Berdasarkan kriteria di atas, Gardner menggolongkan kemampuan manusia ke dalam sembilan jenis kecerdasan. Kecerdasan-kecerdasan itu adalah kecerdasan verbal/linguistik (verbal/linguistic intelligence), kecerdasan visual/spasial (visual/spatial intelligence), kecerdasan logikal-matematis (logical-mathematical intelligence), kecerdasan musikal (musical intelligence), kecerdasan tubuh/kinestetik (bodily/kinesthetic intelligence), kecerdasan interpersonal (interpersonal intelligence), kecerdasan intrapersonal (intrapersonal intelligence), kecerdasan naturalis (naturalist intelligence), dan kecerdasan eksistensial (existential intelligence). 


\section{METODE}

\section{Metode Penelitian}

Penelitian ini bertujuan untuk mendeskripsikan

penerapan

pembelajaran matematika yang melibatkan kecerdasan majemuk dengan pendekatan saintifik, sehingga pendekatan penelitian yang sesuai adalah pendekatan kualitatif dengan jenis penelitian tindakan kelas (PTK).

\section{Tempat dan Waktu Penelitian}

Penelitian ini akan dilaksanakan di MTs Nurul Huda Beringin pada siswa kelas VIII A yang berjumlah 39 siswa dengan mengambil materi Relasi dan Fungsi, pada bulan Agustus sampai dengan Nopember 2016.

\section{Data dan Sumber Data}

Data yang akan diambil pada penelitian ini meliputi: (1) data validasi perangkat pembelajaran, (2) hasil belajar siswa terkait keberhasilan dalam standart kompetensi dan kompetensi dasar yang menjadi materi penelitian, (3) hasil observasi pembelajaran terkait aktivitas guru dan siswa, (4) hasil wawancara, dan (5) dokumentasi. Sumber data dalam penelitian ini adalah peneliti, guru, siswa, validator dan obesrver.

\section{Prosedur Pengumpulan Data}

Selama proses penelitian, peneliti mengumpulkan berbagai data yang terkait dengan penelitian. Berikut penjelasan bentuk data dan proses memperolehnya, yaitu : (a) Data validasi, Data validasi merupakan skor penilaian terhadap validitas RPP, LKS, soal tes awal dan soal tes akhir siklus, dan lembar observasi yang diperoleh dari lembar validasi yang diisi oleh validator. (b) Hasil Belajar Siswa, Hasil belajar siswa bersumber dari tes awal dan tes akhir siklus. (c)

\section{Hasil Observasi Aktivitas} pembelajaran, Data laporan observasi aktivitas pembelajaran diperoleh dari hasil lembar observasi yang diisi para observer ketika proses pembelajaran berlangsung, aktivitas yang diobservasi adalah aktivitas guru dan aktivitas siswa dalam proses permbelajaran. (d) Hasil Wawancara, Data berupa hasil wawancara diperoleh dari wawancara antara peneliti dengan beberapa orang siswa.

\section{Analisis Data}

Analisis data dalam penelitian ini meliputi analisis kuantitatif dan analisis kualitatif. Analisis kuantitatif diperoleh dari data hasil validasi, data observasi aktivitas pembelajaran, dan hasil belajar siswa. Dengan kriteria keberhasilan

- Keberhasilan Validitas

Perangkat dan Instrumen Penelitian dikatakan layak digunakan dalam penelitian jika nilai rata-rata validitas dari ketiga validator terletak pada kategori "Cukup Valid".

- Aktivitas Pembelajaran.

Aktivitas pembelajaran dikatakan berhasil jika nilai observasi aktivitas guru dan siswa minimal pada kategori "Baik".

- Hasil belajar siswa dikatakan berhasil jika berada pada kategori tuntas yaitu $75<T \leq 100$ dan kategori tersebut dapat dicapai 
minimal $75 \%$ siswa.

Analisis data kualitatif pada penelitian ini menggunakan analisis data model Miles dan Huberman. Menurut Miles dan Huberman (dalam Sugiyono, 2013), aktivitas dalam analisis data kualitatif dilakukan secara interaktif dan terus menerus sampai tuntas, hingga datanya jenuh. Aktivitas yang dilakukan dalam penelitian kualitataif pada penelitian ini adalah mereduksi data, menyajikan data, dan menarik kesimpulan. Setelah dilakukan proses analisis data, tahap selanjutnya adalah evaluasi. Pada tahap evaluasi peneliti mengamati dengan teliti tindakan pada siklus I. Setelah tahap evaluasi selesai, peneliti melakukan refleksi. Pada tahap refleksi, peneliti memperbaiki berbagai hal yang kurang efektif pada penelitian.

\section{PEMBAHASAN}

Berdasarkan hasil penelitian yang telah diuraikan, diperoleh informasi bahwa pembelajaran matematika yang melibatkan kecerdasan majemuk dengan pendekatan saintifik pada materi relasi dan fungsi da[at meningkatkan hasil belajar matematika siswa MTs Nurul Huda Beringin kelas VIII A. Hal ini didasarkan pada : (1) nilai tes akhir yang mencapai KKM, (2) hasil observasi aktivitas guru dan siswa selama pembelajaran, dan (3) hasil wawancara yang berfungsi untuk mendukung data hasil observasi maupun data hasil tes.

Tes akhir pada suatu siklus diperlukan untuk mengetahui pemahaman siswa terhadap suatu materi yang dipelajari dalam suatu siklus. Berkurangnya kesalahan konsep, prosedur maupun kalkulasi yang nampak pada pekerjaan siswa dapat menunjukkan bahwa siswa tersebut makin paham tentang materi yang dipelajari. Hal tersebut sesuai dengan yang dikatakan Arikunto (2010:194) bahwa untuk mengukur pencapaian seseorang setelah mempelajari sesuatu dilakukan tes.

Observasi aktivitas guru dan siswa selama pembelajaran dilaksanakan untuk mengamati kesesuaian seluruh aktivitas yang dilakukan guru dan siswa dengan rancangan yang dituangkan pada RPP. Hal ini sesuai dengan yang diungkapkan Fraenkel (2012) bahwa cara terbaik untuk menjawab pertanyaan-pertanyaan penelitian adalah melalui observasi tentang bagaimana orang berprilaku atau bagaimana sesuatu nampak. Peneliti dapat bertanya kepada guru-guru tentang bagaimana murid-murid mereka berprilaku selama pembelajaran, tetapi petunjuk yang lebih akurat dapat diperoleh melalui pengamatan langsung ketika pembelajaran berlangsung.

Wawancara dilakukan setelah semua tindakan selesai. Selain untuk memperkuat data hasil observasi maupun data hasil tes, wawancara juga digunakan untuk mengetahui pemahaman siswa tentang materi luas permukaan bangun ruang. Pedoman wawancara dibuat untuk mengarahkan 
pewawancara mengenai aspek-aspek apa saja yang perlu ditanyakan. Pedoman wawancara memberi kesempatan pewawancara untuk memikirkan bagaimana aspek-aspek tersebut akan dijabarkan atau disesuaikan dengan konteks/keadaan aktual saat wawancara berlangsung. Hal ini sesuai dengan pernyataan Fraenkel (2012) bahwa data yang diperoleh akan sistematik dengan menggunakan pedoman wawancara.

Bab ini menguraikan tentang: (a) penerapan pembelajaran matematika yang melibatkan kecerdasan majemuk dengan pendekatan saintifik pada materi relasi dan fungsi; (b) Prestasi belajar siswa pada tes akhir siklus tentang materi relasi dan fungsi; (c) aktivitas belajar siswa dalam penerapan pembelajaran matematika yang melibatkan kecerdasan majemuk dengan pendekatan saintifik; dan d) kendala-kendala dalam penelitian dan solusinya.

\section{Penerapan \\ Matematika yang Melibatkan \\ Kecerdasan Majemuk dengan \\ Pendekatan Saintifik pada Materi Relasi dan Fungsi}

Penelitian ini menggunakan pendekatan saintifik dengan melibatkan kecerdasan majemuk dalam membelajarkan materi relasi dan fungsi untuk kelas VIII A MTs Nurul Huda Beringin kabupaten Cirebon.

$$
\text { Pembelajaran dengan }
$$
pendekatan saintifik adalah proses pembelajaran yang dirancang sedemikian rupa agar peserta didik secara aktif mengonstruk konsep, hukum atau prinsip melalui tahapantahapan mengamati (untuk mengidentifikasi atau menemukan masalah), merumuskan masalah, mengajukan atau merumuskan hipotesis, mengumpulkan data dengan berbagai teknik, menganalisis data, menarik kesimpulan dan mengomunikasikan konsep, hukum atau prinsip yang "ditemukan". Pendekatan saintifik dimaksudkan untuk memberikan pemahaman kepada peserta didik dalam mengenal, memahami berbagai materi menggunakan pendekatan ilmiah, bahwa informasi bisa berasal dari mana saja, kapan saja, tidak bergantung pada informasi searah dari guru. Oleh karena itu kondisi pembelajaran yang diharapkan tercipta diarahkan untuk mendorong peserta didik dalam mencari tahu dari berbagai sumber melalui observasi, dan bukan hanya diberi tahu.

Metode saintifik sangat relevan dengan tiga teori belajar yaitu teori Bruner, teori Piaget, dan teori Vygotsky. Teori belajar Bruner disebut juga teori belajar penemuan. Ada empat hal pokok berkaitan dengan teori belajar Bruner (dalam Carin \& Sund, 1975). Pertama, individu hanya belajar dan mengembangkan pikirannya apabila ia menggunakan pikirannya. Kedua, dengan melakukan proses-proses kognitif dalam proses penemuan, siswa akan memperoleh sensasi dan 
kepuasan intelektual yang merupakan suatau penghargaan intrinsik. Ketiga, satu-satunya cara agar seseorang dapat mempelajari teknik-teknik dalam melakukan penemuan adalah ia memiliki kesempatan untuk melakukan penemuan. Keempat, dengan melakukan penemuan maka akan memperkuat retensi ingatan. Empat hal di atas adalah bersesuaian dengan proses kognitif yang diperlukan dalam pembelajaran menggunakan metode saintifik.

Teori Piaget, menyatakan bahwa belajar berkaitan dengan pembentukan dan perkembangan skema (jamak skemata). Skema adalah suatu struktur mental atau struktur kognitif yang dengannya seseorang secara intelektual beradaptasi dan mengkoordinasi lingkungan sekitarnya (Baldwin, 1967). Skema tidak pernah berhenti berubah, skemata seorang anak akan berkembang menjadi skemata orang dewasa. Proses yang menyebabkan terjadinya perubahan skemata disebut dengan adaptasi. Proses terbentuknya adaptasi ini dapat dilakukan dengan dua cara yaitu asimilasi dan akomodasi. Asimilasi merupakan proses kognitif yang dengannya seseorang mengintegrasikan stimulus yang dapat berupa persepsi, konsep, hukum, prinsip ataupun pengalaman baru ke dalam skema yang sudah ada didalam pikirannya. Akomodasi dapat berupa pembentukan skema baru yang dapat cocok dengan ciri-ciri rangsangan yang ada atau memodifikasi skema yang telah ada sehingga cocok dengan ciri-ciri stimulus yang ada. Dalam pembelajaran diperlukan adanya penyeimbangan atau ekuilibrasi antara asimilasi dan akomodasi.

Vygotsky, dalam teorinya menyatakan bahwa pembelajaran terjadi apabila peserta didik bekerja atau belajar menangani tugas-tugas yang belum dipelajari namun tugastugas itu masih berada dalam jangkauan kemampuan atau tugas itu berada dalam zone of proximal development daerah terletak antara tingkat perkembangan anak saat ini yang didefinisikan sebagai kemampuan pemecahan masalah di bawah bimbingan orang dewasa atau teman sebaya yang lebih mampu. (Nur dan Wikandari, 2000).

Berikut disajikan langkahlangkah penerapan pembelajaran matematika yang melibatkan kecerdasan majemuk dengan pendekatan saintifik.

\section{1) Pendahuluan}

Pada kegiatan pendahuluan ini pembelajaran dibuka dengan mengucapkan salam, meminta ketua kelas untuk memimpin berdoa, menanyakan kabar siswa, mengecek kehadiran siswa, memberikan apersepsi sesuai sub materi yang akan dipelajari, menyampaikan tujuan pembelajaran dan membentuk kelompok belajar. Kecerdasan majemuk yang terlibat pada kegiatan pendahuluan ini adalah kecerdasan linguistic, kecerdasan interpersonal, kecerdasan intrapersonal dan kecerdasan kinestetik. 
Menurut Ausubel (dalam Orton, 2004) faktor yang paling penting yang mempengaruhi belajar ialah apa yang telah diketahui siswa agar siswa mampu mengaitkan konsep dan informasi baru dengan konsep yang telah ada dan telah terstruktur di dalam kognitif siswa. Sesuai dengan cumulative learning theory yang diungkapkan Robert Gagne (dalam Resnick, 1981) bahwa konsep yang baru diterima oleh siswa tergantung dengan konsep lama yang telah diperoleh siswa sebelumnya. Konsep baru yang terbentuk merupakan kombinasi dari konsep-konsep lain yang lebih sederhana. Pemahaman konsep siswa tentang luas permukaan bangun ruang perlu didukung dengan pengetahuan siswa sebelumnya tentang konsep relasi dan fungsi.

\section{2) Kegiatan inti \\ a. Mengamati}

Pada tahapan ini guru memberikan permasalahan kepada siswa tentang materi relasi dan fungsi untuk diamati dan dicermati siswa, masalah bisa diberikan melalui tayangan slide power poin atau melalui lembar kerja siswa. Kecerdasan majemuk yang terlibat dalam tahap ini ada adalah kecerdasan visual siswa.

Metode mengamati mengutamakan kebermaknaan proses pembelajaran (meaningfull learning). Metode ini memiliki keunggulan tertentu, seperti menyajikan media obyek secara nyata, peserta didik senang dan tertantang, danmudah pelaksanaannya. Metode mengamati sangat bermanfaat bagi pemenuhan rasa ingin tahu peserta didik. Sehingga proses pembelajaran memiliki kebermaknaan yang tinggi. Hal ini sesuai dengan pendapat Ausubel dan Novak (1977) bahwainformasi yang tersubsumsi berakibat peningkatan diferensiasi dari subsume subsume, jadi memudahkan proses belajar berikutnya untuk materi belajar yang mirip.

\section{a. Menanya}

Pada tahapan ini guru meminta siswa untuk membuat pertanyaan tentang materi relasi dan fungsi, kemudian apabila siswa kesulitan dalam membuat pertanyaan maka guru memberikan pertanyaan pancingan untuk mengarahkan siswa kepada pertanyaan yang menjadi konsep dari materi relasi dan fungsi yang dipelajari. Kecerdasan majemuk yang terlibat dalam tahapan ini adalah kecerdasan linguistik, kecerdasan interpersonal dan kecerdasan logika.

Melalui kegiatan bertanya dikembangkan rasa ingin tahu peserta didik. Semakin terlatih dalam bertanya maka rasa ingin tahu semakin dapat dikembangkan. Pertanyaan terebut menjadi dasar untuk mencari informasi yang lebih lanjut dan beragam dari sumber yang ditentukan guru sampai yang ditentukan peserta didik, dari sumber yang tunggal sampai sumber yang beragam. 
b. Mengumpulkan informasi

Kegiatan mengumpulakan informasi dilakukan dengan meminta siswa untuk mengumpulkan informasi dengan membaca dan mengamati dengan teliti pada buku siswa atau lembar kerja siswa, sehingga siswa memperoleh informasi untuk menyelesaikan permasalahan pada materi relasi dan fungsi yang diberikan oleh guru. Kecerdasan majemuk yang terlibat dalam tahapan ini adalah kecerdasan logika, kecerdasan interpersonal dan kecerdasan linguistik. Dalam kegiatan mengumpulkan informasi ini siswa menggali dan mengumpulkan informasi dari berbagai sumber melalui berbagai cara, sehingga siswa mampu mengaitkan konsep yang sudah diketahuinya dengan konsep baru yang diperoleh dengan membaca atau mengamati berbagai sumber. Sedangkan untuk memfasilitasi kecerdasan musikal guru memberikan ice braking berupa permainan atau menyanyikan lagu yang berhubungan dengan relasi dan fungsi.

Menurut Ausubel (Orton, 2004) faktor yang paling penting yang mempengaruhi belajar ialah apa yang telah diketahui siswa agar siswa mampu mengaitkan konsep dan informasi baru dengankonsep yang telah ada dan telah terstruktur di dalam kognitif siswa. Sesuai dengan cumulative learning theory yang diungkapkan Robert Gagne (dalam Resnick, 1981) bahwa konsep yang baru diterima oleh siswa tergantung dengan konsep lama yang telah diperoleh siswa sebelumnya. Konsep baru yang terbentuk merupakan kombinasi dari konsep-konsep lain yang lebih sederhana. Pemahaman konsep siswa tentang luas permukaan bangun ruang perlu didukung dengan pengetahuan siswa sebelumnya tentang konsep relasi dan fungsi.

\section{c. Mengasosiasi}

Kegiatan mengasosiasi secara umum dilakukan dengan guru meminta siswa untuk menyelesaikan permasalahan pada lembar kerja siswa yang diberikan. memproses informasi yang sudah dikumpulkan baik terbatas dari hasil kegiatan mengumpulkan/eksperimen maupun hasil dari kegiatan mengamati dan kegiatan mengumpulkan informasi. Pengolahan informasi yang dikumpulkan dari yang bersifat menambah keluasan dan kedalaman sampai kepada pengolahan informasi yang bersifat mencari solusi dari berbagai sumber yang memiliki pendapat yang berbeda sampai kepada yang bertentangan. Kegiatan ini dilakukan untuk menemukan keterkaitan satu informasi dengan informasi lainya, menemukan pola dari keterkaitan informasi tersebut. Kecerdasan majemuk yang terlibat pada tahapan ini adalah kecerdasan logika dan kecerdasan interpersonal.

Menurut Johnson (2003), ketika siswa dapat mengaitkan isi dari pelajaran akademik seperti matematika, ilmu pengetahuan alam, atau sejarah dengan pengalaman mereka sendiri, mereka dapat menemukan makna dan makna akan mendorong mereka untuk tertarik belajar. Dalam kegiatan ini siswa 
dengan kelompoknya bersama-sama memecahkan masalah pada lembar kerja siswa, sehingga siswa merasa senang ketika dapat memecahkan masalah yang diberikan. Hal ini sejalan dengan pendapat Smith (2010) bahwa bekerja secara bersama-sama membuat siswa merasa senang. Kesenangan itu ditimbulkan karena bisa memberikan bantuan kepada teman yang lain dan secara bersamasama bisa memahami suatu materi.

\section{d. Mengkomunikasikan}

Pada kegiatan ini guru memberikan kesempatan kepada perwakilan kelompok untuk mempresentasikan hasil diskusi kelompok di depan kelas, dan kelompok lain memberikan tanggapan terhadap materi yang dipresentasikan, kecerdasan majemuk yang terlibat dalam tahap ini adalah kecerdasan logika, kecerdasan interpersonal dan kecerdasan linguistik. Kegiatan ini diakhiri dengan guru memberikan umpan balik terhadap hasil presentasi dan diskusi siswa pada materi relasi dan fungsi.

\section{e. Penutup}

pada kegiatan ini guru dan siswa membuat kesimpulan secara bersamasama, memberikan kuis, memberikan pekerjaan rumah, menyampaikan materi pada pertemuan berikutnya dan menutup pembelajaran dengan berdoa. Kecerdasan majemuk yang terlibat pada tahapan ini adalah kecerdasan intrapersonal, kecerdasan logika dan kecerdasan linguistik.

Pemberian pekerjaan rumah dimaksudkan agar siswa terampil dalam memecahkan masalah rutin, sehingga pemahaman konsep dari materi yang dipelajari semakin bagus. Hal ini sejalan dengan Van de Walle (2008) pekerjaan rumah adalah cara yang sangat sesuai digunakan siswa untuk terlibat dalam kegiatan berbasis soal. Kegiatan berbasis soal dapat menguntungkan untuk diberikan sebagai pekerjaan rumah asalkan tingkat kesulitannya masih dalam jangkauan siswa.

Prestasi Belajar Siswa pada Tes Akhir Siklus tentang Materi Relasi dan Fungsi

Analisis yang dilakukan terhadap hasil tes akhir adalah mengidentifikasi kesalahan yang dilalukan siswa dalam mengerjakan soal. Adapun kriteria keberhasilan penelitian ini adalah apabila lebih dari $75 \%$ siswa mendapatkan skor tes akhir siklus lebih besar atau sama dengan 75. Pada siklus I, pencapaian prestasi belajar siswa kelas VIII-A adalah sebanyak 18 siswa atau $46 \%$ siswa memperoleh nilai akhir lebih dari 75 . Pada siklus II, pencapaian prestasi belajar siswa kelas VIII-A adalah Sebanyak 31 siswa atau $80 \%$ siswa memperoleh skor akhir lebih dari atau sama dengan 75. Sehingga peningkatan pencapaian prestasi belajar dari siklus I dan siklus II adalah sebesar $34 \%$.

\begin{tabular}{|c|c|c|}
\hline $\begin{array}{l}\text { Aktivitas } \\
\text { Penerapan }\end{array}$ & Belajar & $\begin{array}{c}\text { Siswa dalam } \\
\text { Pembelajaran }\end{array}$ \\
\hline Matematika & yang & Melibatkan \\
\hline Cecerdasan & Maje & dengan \\
\hline
\end{tabular}


Pada siklus I, rata-rata hasil observasi aktivitas siswa pada pertemuan pertama dalam kategori kurang baik dengan persentase $65 \%$ dan pada pertemuan kedua dalam kategori cukup dengan persentase 75\%. Pada siklus II, rata-rata hasil observasi aktivitas siswa pada pertemuan pertama dalam kategori baik dengan persentase $81 \%$ dan pada pertemuan kedua dalam kategori baik dengan persentase $83 \%$.

\section{Kendala-Kendala dalam Penelitian dan Solusinya}

Menurut peneliti terdapat beberapa hal yang menjadi kunci keberhasilan tindakan dalam penelitian. Pertama peneliti dan guru membentuk kelompok yang heterogen. Pencampuran siswa dengan level kemampuan yang beragam akan memperbanyak bantuan dalam suatu kelompok. Thompson (Isjoni, 2009) mengemukakan bahwa pembelajaran kooperatif turut menambah unsurunsur interaksi sosial pada pembelajaran.

Kedua, peneliti mengurangi pembelajaran yang berpusat pada guru, dengan memberikan kesempatan seluas-luasnya kepada siswa untuk mengamati, membuat pertanyaan, menggali informasi pada beberapa sumber belajar, mangasosiasi atau menalar dan mempresentasikan hasil kerja kelompok serta memberikan tanggapan atas presentasi kelompok. Hal ini sesuai dengan pendapat Grouws (1992) bahwa memperluas kesempatan siswa untuk belajar matematika sepenuhnya, bertanya dan mengemukakan pendapat akan menunjang secara langsung dan meyakinkan terhadap capaian dan prestasi siswa.

Ketiga, peneliti dan guru memberikan kesempatan lebih kepada siswa untuk mengerjakan soal-soal dengan tingkat kesulitan yang berbeda melalui latihan soal dan pemberian pekerjaan rumah. Hal ini dimaksudkan agar siswa mempunyai pengetahuan dan wawasan yang cukup atas soalsoal yang bias diselesaikan dengan penerapan konsep tertentu. Grouws (1992) menyatakan bahwa siswa memerlukan kesempatan yang cukup untuk melatih atau mempraktekkan apa yang telah dipelajari dan untuk mendapatkan pengalaman dalam menyelesaikan berbagai macam soal yang mana siswa diharapkan bisa mendemontrasikan kompetensinya

Keempat, peneliti dan guru memberikan motivasi pada siswa. Williams (2007) menyatakan bahwa motivasi menjadi faktor yang sangat penting yang harus didapatkan oleh pendidik dalam upaya memperbaiki pembelajaran. Pemberian motivasi pada siswa bias dilakukan dengan dua cara, diantaranya: (1) Memberikan dorongan/encouragement dan pujian/praise. Hal ini dilakukan peneliti dan guru setiap kali seorang siswa mengajukan pertanyaan, mengemukakan pendapat, menjawab pertanyaan dan menanggapi jawaban atau presentasi dari siswa yang lain. 
Memberikan dorongan dalam bentuk kata-kata positif dan pujian sangat mempengaruhi motivasi siswa (Palmer, 2007) dan (2) memberikan penguatan/reinforcement. Strategi penguatan yang bisa dilakukan diantaranya dengan meriview konsep yang sudah diperoleh (Carrel, 1997). Setiap tahap generalisasi maupun tahap penutup, peneliti bersama-sama siswa mereview dan menyatakan kembali konsep-konsep yang ditemukan pada kegiatan pembelajaran sebelumnya.

\section{TEMUAN PENELITIAN}

Berikut adalah beberapa temuan yang diperoleh peneliti selama melakukan penelitian.

a. Dari seluruh pembelajaran yang diterapkan, penelitian ini menghasilkan langkah-langkah pembelajaran matematika yang melibatkan kecerdasan majemuk dengan pendekatan saintifik pada materi relasi dan fungsi.

b. Respon siswa selama mengikuti pembelajaran matematika yang melibatkan kecerdasan majemuk dengan pendekatan saintifik pada materi relasi dan fungsi adalah siswa lebih mudah memahami dan mengingat konsep tentang relasi dan fungsi, selain itu pembelajaran matematika yang melibatkan kecerdasan majemuk dengan pendekatan saintifik menyenangkan dan dapat menambah motivasi belajar.

c. Berdasarkan tindakan yang dilakukan peneliti, terdapat beberapa hal yang mempengaruhi keberhasilan tindakan pada siklus II diantaranya:

1) Memberikan masukan kepada guru mengenai manajemen waktu dan kelas, sehingga penerapan pembelajaran matematika yang melibatkan kecerdasan majemuk dengan pendekatan saintifik bisa terlaksana dengan baik sesuai dengan RPP yang telah disepakati.

2) Mengubah anggota kelompok belajar siswa menjadi lebih heterogen dengan kemampuan akademik siswa, sehingga membuat proses pembelajaran dalam kelompok menjadi lebih aktif dan efektif.

3) Mengurangi pembelajaran yang berpusat pada guru, dengan memberikan kesempatan seluas-luasnya kepada siswa untuk mengamati, membuat pertanyaan, menggali informasi pada beberapa sumber belajar, mangasosiasi atau menalar dan mempresentasikan hasil kerja kelompok serta memberikan tanggapan atas presentasi kelompok.

4) Memberikan kesempatan lebih kepada siswa untuk mengerjakan soal-soal dengan tingkat kesulitan yang berbeda melalui latihan soal dan pemberian pekerjaan rumah.

Memberikan motivasi belajar kepada siswa dalam bentuk kata-kata positif, pujian dan penguatan melalui hadiah sehingga dapat meningkatkan prestasi belajar siswa. 
KESIMPULAN DAN SARAN

\section{Kesimpulan}

Pembelajaran matematika yang melibatkan kecerdasan majemuk dengan pendekatan saintifik dilaksanakan dengan langkah-langkah: 1) kegiatan pendahuluan; 2) kegiatan inti yang terdidi dari mengamati, menanya, mengumpulkan informasi, mengasosiasi, dan mengkomunikasikan; dan 3) penutup. Sedangkan kecerdasan majemuk yang terlibat dalam pembelajaran adalah kecerdasan verbal/lingusitik, kecerdasan visual/spasial, kecerdasan logikal/matematis, kecerdasan musikal, kecerdasan tubuh/kinestetik, kecerdasan interpersonal, dan kecerdasan intrapersonal.

Pada siklus I, pencapaian prestasi belajar siswa kelas VIII-A adalah sebanyak 18 siswa atau $46 \%$ siswa memperoleh nilai akhir lebih dari 75. Pada siklus II, pencapaian prestasi belajar siswa kelas VIII-A adalah Sebanyak 31 siswa atau $80 \%$ siswa memperoleh skor akhir lebih dari 75. Sehingga peningkatan pencapaian prestasi belajar dari siklus I dan siklus II adalah sebesar $34 \%$. Pada siklus I, rata-rata hasil observasi aktivitas siswa pada pertemuan pertama dalam kategori kurang baik dengan persentase $65 \%$ dan pada pertemuan kedua dalam kategori cukup dengan persentase $75 \%$. Pada siklus II, rata-rata hasil observasi aktivitas siswa pada pertemuan pertama dalam kategori baik dengan persentase $81 \%$ dan pada pertemuan kedua dalam kategori baik dengan persentase $83 \%$

\section{Saran}

1. Penggunaan ice breaking pada pembelajaran matematika yang melibatkan kecerdasan majemuk dengan pendekatan saintifik perlu dikembangkan dengan ice breaking lainnya, bisa permainan atau video penggugah motivasi siswa, sehingga selain aspek kognitif, unsur penanaman moral kepada siswapun akan tersampaikan dengan baik.

2. Scaffolding atau pemberian bantuan oleh siswa atau guru dalam pembelajaran perlu dirancang dan disiapkan dengan lebih terstruktur, agar ketika proses menanya atau mengasosiasi tidak berjalan sesuai rencana, guru bisa mengatasinya dengan baik.

\section{DAFTAR PUSTAKA}

Arikunto, S. 2010. Prosedur Penelitian Suatu pendekatan praktik. Jakarta: PT. Rineka Cipta. Azrul, A. 2005. Manajemen laktasi. Jakarta.

Ausubel, D. P. \& Novak, J. D. 1977. Educational Psycology : A Cognitif View. New York: Holt, Rinehart and Winston.

Baldwin, A. L. 1967. Theories of Child Development. Chicago : John Wiley \& Sons, inc.

Carrel, Alexis, Man: The Unknown, Bombay: Willco Publishing House.

Clarin, A . A \& Sund, R .B. 1975. Teaching Science Thorgh Discovery. Thir Editional Charles 
Merril Publishing Company. Columbus. Ohio.

D'Souza, N. 2007. Design Intelligences: A Case for Multiple Intelligences in Architectural Design. Archnet-IJAR, International Journal of Architectural Research - Volume 1 - Issue 2, pg. 15 - 34.

DePorter, B. Mark R., \& Sarah S.N. 1999. Quantum Teaching: Orchestrating Student Success. Terjemahan oleh Ary Nilandari (Quantum Teaching: Mempraktikkan Quantum Learning di Ruang-ruang Kelas). 2007. Bandung: Kaifa

Efendi, A. 2005. Revolusi Kecerdasan Abad 21 Kritik MI, SQ, AQ \& Succes Intelligence Atas IQ. Bandung: Alfabeta.

Fraenkel, J . P \& Wallen N. E. 2012. How To Design and Evaluate Research in Education. New York. McGraw-hillCompanies. Inc

Gardner, H. 2011. Frame of Mind (second edition). New York: Basic Book

Grows, D.A. 1992. Handbook of Research on Mathematics Teaching and Learning. New York : Macmillan Publishing Co.

Isjoni. 2009. Cooperative Learning. Bandung : Alfabeta.

Johnson, D.W., Johnson, R.T. \& Johnson-Holubec, E.J. 2003. Cooperation in the Classroom. Bandung: Alfabeta.

Nur, M. dan Wikandari, P.R. 2000. Pengajaran Berpusat kepada Siswa dan Pendekatan Konstruktivistik dalam
Pengajaran. Surabaya: Universitas Neger Surabaya.

Orton, D.I, Wilkinson, J.D. 2004. Cosmetic Allergy: Incidence, Diagnosis and Management. Am $\mathrm{J}$ Clin Dermatol.

Palmer \& Williams. (2007). Tekanan Darah Tinggi. Jakarta: Erlangga

Resnick. 1981. L.B. The Psychologi of Mathematic for Instruction. Hillsdale Lawrence Elrbaum Associates, Inc.

Smith, R. J., et al. 2010. Management The Third Stage of Labor, Medscape reference, Available from http://emedicine.medscape.com/art icle/275304-overview

Sugiyono. 2009. Metode Penelitian Kuantitatif Kualitatif dan $R \& D$. Bandung: Alfabeta.

Van De Walle, John. A. 2008. Matematika Sekolah Dasar Dan Menengah. Jakarta: Erlangga.

Williams, B. K., \& Sawyer, S. C. (2007). Using Information Technology: Pengenalan Praktis Dunia Komputer dan Komunikasi (Edisi 7) (Penerjemah: Nur Wijayaning Rahayu \& Th. Arie Prabawati). Yogyakarta: 